\title{
Development of Christian Character Education Based Project Based Learning Teaching Materials to Improve Student Character
}

\author{
Melur Dewi Andriaty Zendrato, Suharno, Leo Agung
}

Universitas Sebelas Maret, Surakarta, Indonesia

\begin{abstract}
Character education plays an important role in creating students who have good character. Christian schools have to provide project-based teaching materials so that students not only know a good character but also able to apply them in everyday life.This study uses quantitative methods to examine the use of Christian character education teaching materials based on project-based learning. The study was conducted on 8th-grade students at Kalam Kudus Christian Junior High School Surakarta. The results showed that the use of project-based learning Christian character education materials had an effective impact on improving student character.
\end{abstract}

Keywords-Character Education, Teaching Materials, Project-Based Learning.

\section{INTRODUCTION}

Character education is an important thing to do in this day and age. A character becomes one of the determinants of a person's success in living his life.Character education will help students to develop the main values in life such as justice, craft, respect and they will understand the reasons why they need to be done in life. Character education will also have an impact on increasing student awareness of their roles and responsibilities as community groups in the life of the nation and state (Aynur Pala, 2011: 23-32). The process of developing superior human resources cannot be separated from the role of educational institutions. The purpose of national education is to educate the life of the nation and develop people who have the attitudes, knowledge, and skills needed for the progress of the nation. Thus it can be said that educational institutions, namely schools, have an important role in creating superior human resources.

This also applies to Christian education as a means of achieving the goals of National Education. Michael J. Anthony (2001: 16) defines Christian education as a process in which someone who experiences a new birth in God, when the Holy Spirit lives in him, experiences growth to be like Christ. This process occurs when a person studies God's word and applies what he learns in daily life. This is lifelong learning. That means that Christian education has to build superior quality human resources and be fruitful in their lives.
One Christian educational institution that has an important role in shaping human resources is the school. Lockerbie (2008:15) states that a Christian school exists by centering on God and based on Bible truth. Thus Christian schools have a clear purpose, that is, goals that are based on what is in the Bible. Christian schools aim to educate students so that they can glorify God, tell about God to the world, and have grown in knowledge and action. Growing to be like Christ is the goal of Christian education, so that education must not stop only with the knowledge of how to live this life, but also how to live this life.

Some Christian schools have included character education in their curriculum but in its journey, it was found that character education often only stopped at the knowledge of the character and did not materialize in real action. Thomas Lickona (2012:51) states that characters consist of values that work in a person (operative values), values in action. A person's character develops as values develop into virtue. Characters talk about what is in a person. The character will determine how a person acts when he thinks that he is not seen by others. Or in other words, the characters talk about what someone does when no one sees it.

Lickona in her book Raising Good Children (2004:7) states that the characters contain three interrelated parts namely moral knowledge, moral feelings, and moral actions. Good character consists of knowing good, wanting good, and doing good. That means, having habits in the 
mind, habits in the heart, and habits in action. These three things are important to lead a moral life and even moral maturity.

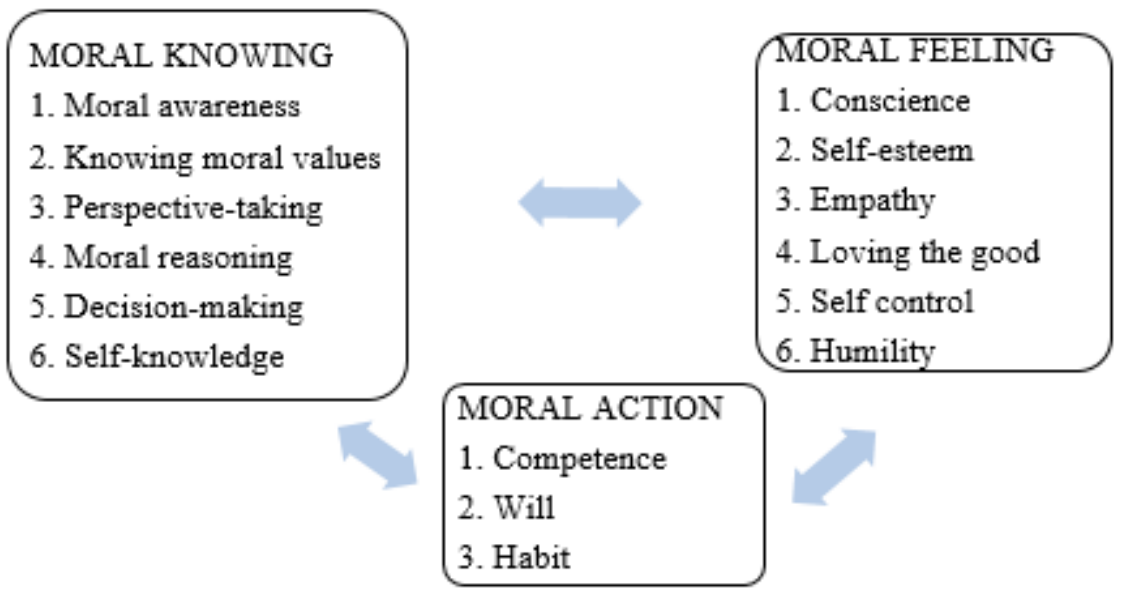

Fig.1: Character Components
This understanding should awaken Christian schools to not only teach character education but must carry out character education that encourages students to manifest good character in their daily lives. That is why it is necessary to develop project-based character education teaching materials that will guide students to practice good character life.

Teaching materials are all forms of materials used by teachers/instructors in carrying out the teaching and learning activities referred to in the form of written or unwritten materials. Teaching materials enable students to learn a basic competency or competency coherently and systematically so that they can master all competencies in an integrated and integrated manner. Teaching materials are information, tools, and texts needed by the teacher/instructor for planning and studying the implementation of learning. Teaching material is any form of material or material that is arranged systematically and is used to help the teacher or instructor in carrying out teaching and learning activities to create an environment or atmosphere that allows students to learn. (Prastowo, 2012:16)

According to Majid (2006:12), teaching materials can be written or unwritten materials. The teaching material group consists of integrated writing, audio-visual, electronic, and interactive media groups. A teaching material at least includes study instructions (student/ teacher instructions), competencies to be achieved, supporting information, exercises, work instructions that can be in the form of worksheets, and evaluations. Teaching materials or instructional materials generally consist of knowledge, skills, and attitudes that students must learn to achieve predetermined competencies. In detail, the types of learning materials consist of knowledge (facts, concepts, principles, procedures), skills, and attitudes or values.

Based on some understanding of teaching materials above, it can be concluded that teaching materials are all kinds of material in the form of written media, audio-visual media, electronics, integrated interactions consisting of knowledge, skills, and attitudes that students must learn to help teachers in the learning process teach to achieve predetermined competencies.

In addition to choosing the right materials, to do a teacher must choose an approach or appropriate learning models also, so that students really feel the significance of the material they are learning. One of them is using the Project-Based Learning (PjBL) model. According to Hanafiah and Suhana (2009:30) the learning model Project-Based Learning is a learning approach that allows students to work independently in constructing their learning and producing it intangible products. Meanwhile, according to Trianto (2014:42) Project Based Learning is a model or innovative learning approach, which emphasizes learning through activities contextual - a complex activity.

From some opinions, it can be concluded that the Project-Based Learning model is an innovative learning model that involves project work where students work independently in constructing their learning and producing it intangible products. In project work contains complex tasks based on very challenging questions and problems and guides students to design, solve problems, make decisions, conduct investigative activities, and provide students the opportunity to work independently. The 
development of teaching material based on project-based learning is expected to be able to encourage students to manifest good character in their daily lives.

\section{METHOD}

The method used in this research is a quantitative method. The quantitative method is a research method that analyzes the number and variables in finding the expected results. Quantitative research uses data analysis based on numbers generated from the use of specific data techniques to answer the question of who, how much, what, when and how (Apuke:2017)

The data collection in this study was conducted by observing learning activities and competency development conducted using character education teaching materials between groups that were given development teaching materials and groups that were not given development teaching materials. Furthermore, interviews were conducted with teachers and students to obtain data on the use of teaching materials in character education in schools. It was also given a questionnaire that aims to find out the character of students who have followed character education so far.

The data that has been collected is then processed to further become a guideline in the preparation of Christian character education teaching materials based on project-based learning. The teaching material that has been compiled is then tested on the validator. Then a small group trial with 5 students was conducted, a large group trial with 10 students, and a large group trial of 26 students. After going through the trial period teaching materials are then implemented in the control class and the experimental class. The results of data acquisition are then analyzed using quantitative methods. This research was conducted to 8th-grade students at the Kalam Kudus Christian Middle School Surakarta.

\section{RESULTS AND DISCUSSION}

\section{Implementation of Character Education}

Based on observations and interviews conducted with teachers and students, it was found that character education at this school was not optimal. This is due to the limited teaching materials used, where they only use one source of character education teaching materials. While students only have a handbook that has been provided by the school, but the explanation of the material from the teacher still uses the conventional learning model.

Each lesson in the core activities is generally an explanation and provision of material by the teacher followed by group assignments, where the work to be done is prepared by the teacher. Each group division was continued with discussion and presentation, but at the time of the discussion, the learning activities were not conducive because of the lack of structured group activity planning. Several groups assign their tasks to one of its members.

Character education which has been running so far also does not encourage students to show good character in their daily lives. During this time they follow character learning as one of the subjects provided by the school. Students know the meaning of good character through the lessons delivered but they have not shown in behavior. Character education in schools should not only provide knowledge to students but also contribute to fostering good attitudes in students interacting well in their environment. Therefore it is very important for character education teachers in teaching true character and encouraging students to realize the true character in their lives. But this has not yet been realized because character education that has been taking place so far is considered unimportant and even tends to be boring. Whereas character education is a subject that should be able to contribute to the values needed in forming true character.

\section{Student Character Analysis}

Researchers conducted an analysis of the implementation of character education in the Kalam Kudus Christian Middle School Surakarta through a questionnaire. The results of the questionnaire are still many students who are not interested in participating in character education. This statement is supported by the teacher himself who says that students often view character education as second class learning. Some students don't listen seriously when learning is delivered. That is because the teaching materials used are monotonous and unattractive. Students also do not show changes in character after following the existing learning. As a result, character education takes place only in the form of understanding concepts without realizing reality in daily life. 


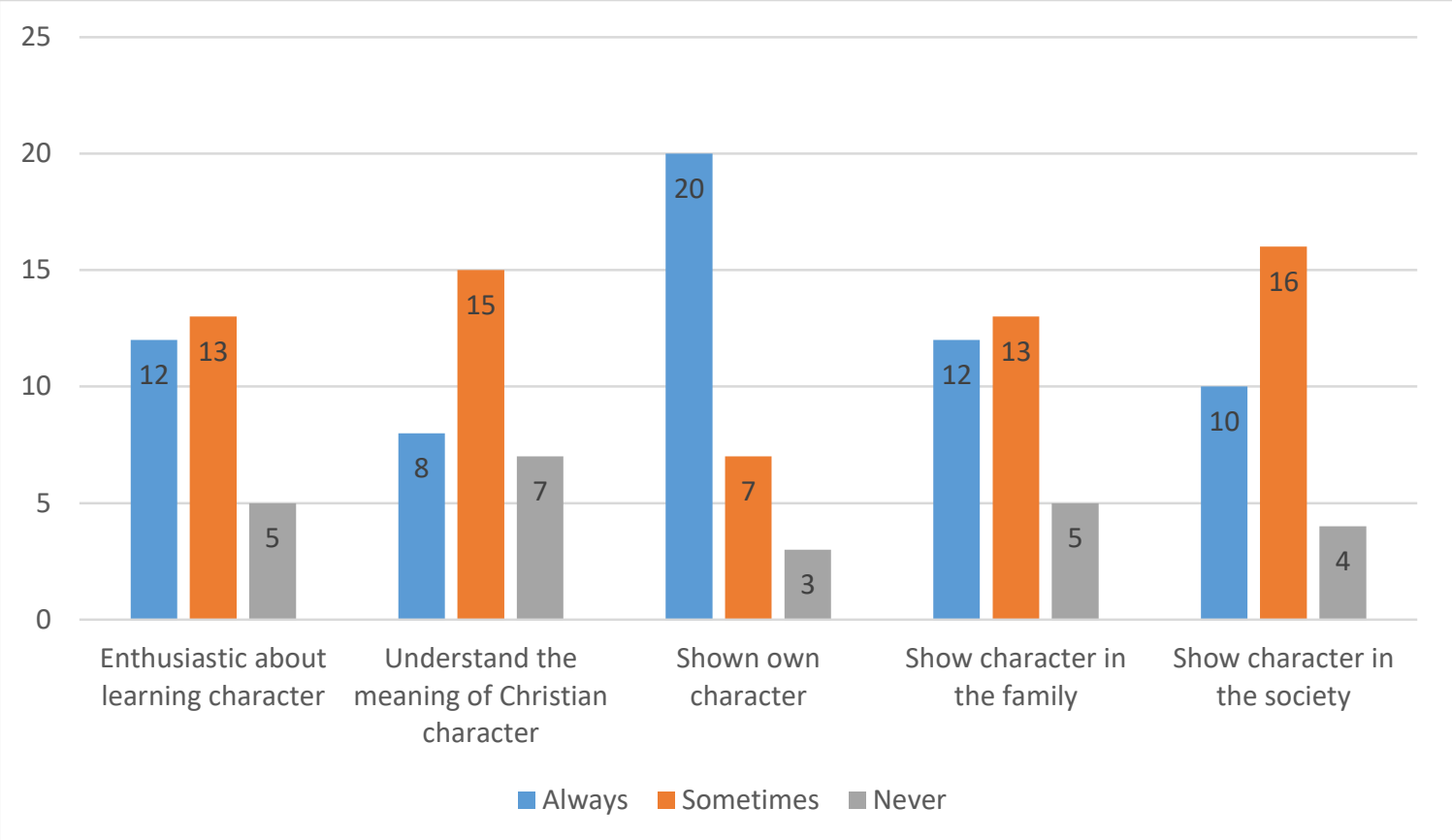

Diagram 1. Student Character Analysis Question Question Diagram

Based on the diagram above, it can be concluded that the character of the students is low. It can be seen from the acquisition of the first indicator data that is students' enthusiasm in participating in character learning from 30 student respondents who answered always were 12 people, while 13 people answered sometimes and 5 people said never. This can indicate that character learning is not interesting to students. Also, understanding the character is by the Christian faith, only correctly interpreted by 8 people, while 15 people say sometimes and 7 people say never. This ultimately has an impact on how students demonstrate character values both for themselves, their families, and the community. Based on the explanation above, there are strong indications that awareness of character values in students' lives needs to be increased. It starts with a correct understanding of the Christian faith which will later have an impact on students' daily lives.

Based on the data that has been obtained, it is compiled teaching materials through the validation test against experts, small group trials, large group trials, and large group trials. Expert validation is a product validation activity that is carried out before being trialed on a limited basis. Validation is done by assessing teaching materials given

to experts, namely Christian education lecturers at STT SAAT, media lecturers at UNS Surakarta, and lecturers on learning materials at UNS Surakarta. The assessment results are as follows:

Table 1. Validation Result

\begin{tabular}{|l|l|l|l|}
\hline NO & $\begin{array}{l}\text { Validation } \\
\text { Material }\end{array}$ & $\begin{array}{l}\text { Average } \\
\text { Validation } \\
\text { Results }\end{array}$ & Information \\
\hline 1 & $\begin{array}{l}\text { Teaching } \\
\text { Material }\end{array}$ & 4,6 & Very good \\
\hline 2 & $\begin{array}{l}\text { Media for } \\
\text { Materials }\end{array}$ & 4,5 & Very good \\
\hline 3 & $\begin{array}{l}\text { Learning } \\
\text { Design }\end{array}$ & 4,8 & Very good \\
\hline
\end{tabular}

After going through the validation process, the teaching of Christian character education based on projectbased learning based on project-based learning is then implemented in two classes, the experimental class and the control class that provide the following results.

\section{A. Test Prerequisites}

Data analysis requirements using parametric statistics are data obtained in normal and homogeneous distribution. Prerequisite test conducted by researchers to determine whether the experimental class and the control class are normally distributed. The researcher gave a pretest in both classes, namely class $8 \mathrm{C}$ as an experimental class and class $8 \mathrm{D}$ as a control class at the Kalam Kudus Christian Middle School in Surakarta. The following results are tests of normality and homogeneity.

\section{Normality test}


In this study, the experimental class normality test uses the Kolmogorov-Smirnov technique with the help of SPSS 20. Data are said to be normally distributed if the significance level is greater than
0.05. Conversely, if the significance level is less than 0.05 , the data is said to be not normally distributed.

Table 2. Tests of Normality

\begin{tabular}{|c|c|c|c|c|c|c|c|c|}
\hline & \multirow{2}{*}{$\begin{array}{l}\text { Ex and } \\
\text { Classes }\end{array}$} & \multirow{2}{*}{ Contro } & \multicolumn{3}{|c|}{ Kolmogorov-Smirnov ${ }^{a}$} & \multicolumn{3}{|c|}{ Shapiro-Wilk } \\
\hline & & & Statistics & df & Sig. & Statistics & df & Sig. \\
\hline Pretest & 1 & &, 099 & 27 & $200^{*}$ & 957 & 27 &, 314 \\
\hline Results & 2 & & 114 & 27 & $200^{*}$ & 959 & 27 &, 353 \\
\hline
\end{tabular}

* This is a lower bound of true significance.

a. Lilliefors Significance Correction

Based on the above output, it is known that the significance value (sig) for all data both in the KolmogorovSmirnov test and the Shapiro-Wilk test indicates more than 0.05 , so it can be concluded that the research data is normally distributed.

Table 3. Test of Homogeneity of Variances Pretest Control and Experiment Classes

Pretest Results

\begin{tabular}{|l|l|l|l|}
\hline Levene Statistics & df1 & df2 & Sig. \\
\hline, 246 & 1 & 52 &, 622 \\
\hline
\end{tabular}

Based on the results of statistical tests with the help of the SPSS 20 program, a significance value of 0.622 is obtained, so it can be said that the control and experimental classes are derived from the same or homogeneous variance. Because the significance value is $0.622>0.05$.

\section{B. Effectiveness Test}

The effectiveness test of Christian character education based on project-based learning is done by comparing the results of the experimental class post-test scores with the results of the control class post-test scores. The results of the post-test scores between the experimental class and the control class were compared to test the average comparison between classes using projectbased learning based Christian character teaching materials developed and classes not using project-based Christian character education teaching materials. See the difference in the average of the experimental class and the control class using the independent samples t-test with the help of the SPSS 20 program.

\section{Homogeneity Test}

After conducting the Normality test, the second condition is the homogeneity test using SPSS 20. The output of the homogeneity test is as follows: 
Table 4. Tests of Normality

\begin{tabular}{|c|l|l|l|l|l|l|l|}
\hline \multicolumn{2}{|l|}{ Experiments \& Control $^{2}$ Kolmogorov-Smirnov a } & \multicolumn{3}{l|}{ Shapiro-Wilk } \\
\cline { 3 - 8 } & & Statistics & df & Sig. & Statistics & df & Sig. \\
\hline $\begin{array}{l}\text { Posttest experimental } \\
\text { class }\end{array}$ &, 103 & 27 &, $200 *$ &, 966 & 27 & 504 \\
Postest control class &, 144 & 27 &, 155 &, 984 & 27 &, 942 \\
\hline
\end{tabular}

* This is a lower bound of true significance.

a. Lilliefors Significance Correction

Based on the results of statistical tests with the help of the SPSS 20 program, it can be concluded that the data are said to be normally distributed if the significance value is greater than 0.05. The obtained significance value of the experimental class posttest is 0.504 and the control class is 0.942 . Then it can be concluded that the posttest scores of the experimental class and the control class are normally distributed.

\section{Homogeneity Test}

Table 5.Test of Homogeneity of Variances

Postest Results

\begin{tabular}{|l|l|l|l|}
\hline Levene Statistics & df1 & df2 & Sig. \\
\hline 634 & 1 & 52 &, 429 \\
\hline
\end{tabular}

Based on the results of statistical tests with the help of the SPSS 20 program, a significance value of 0.429 can be obtained, so it can be said that the pretest and posttest of the experimental class came from the same or homogeneous variance. Because the significance value is $0.429>$ 0.05 .

\section{T-test}

After the t-test requirements are met, namely the normality and homogeneity test, the next step is the $t$-test with the Independent Sample t-test .

Table 6. Test $t$

\begin{tabular}{|l|l|l|l|}
\hline $\mathrm{F}$ & $\mathrm{t}$ & $\mathrm{df}$ & Sig \\
\hline 0.634 & 8,346 & 52 & 0,000 \\
\hline
\end{tabular}

Based on the results of statistical tests with the help of the SPSS 20 program, t value of 8.334 with a significance level of 0.000 is smaller than $0.005(0.000$ $<0.005)$, then Ho is rejected and $\mathrm{Ha}$ is accepted or there is a mean difference between the experimental class and the control class.

Based on the results of this study it was found that there were significant differences in the character awareness of students using Christian character education projects based on project-based learning and conventional character education materials. This is evidenced by the results of statistical tests with a sig value $(0,000<0.005)$. This proves that there is a mean difference between the experimental class and the control class in the results of student character awareness. The conclusion is that the mean values between the experimental and control groups differ. The results of statistical trials in the experimental class have increased both positively and significantly as long as they were given teaching material on Christian character education based on project-based learning. Thus the effectiveness test of teaching material for Christian character education based on project-based learning has met the standards for use in existing learning referring to the results of the pre-test and post-test of two groups given different treatments that can be seen from the results of increasing student character.

\section{DISCUSSION}

Character education is one of the important lessons informing students who have good character. This needs to be done in an interesting and fun learning process. Education that is only centered on the transfer of knowledge will only place students as recipients and not actors of the education itself. One method of character education that is still often done is the lecture method. This method is considered as one of the traditional and monotonous learning methods, but with the limited teaching materials, some teachers still use them. This is consistent with what was conveyed by Sriyono (1992:99) that the lecture method is an explanation delivered by the teacher verbally. Students then listen and record the 
explanation given by the teacher. This lecture method is often used by teachers in conveying learning.

Character education needs to be done in an active dynamic learning process where students are involved to participate in learning activities. Such learning will have a good impact in shaping the character of students. This is following what was stated by Fathurrohman (2017:31) that the characteristics of a good learning model include the involvement of students through experiencing, analyzing, and forming attitudes. There is active and creative participation of students in which the teacher acts as a facilitator and coordinator who motivates student learning activities.

The above understanding encourages teachers to be able to prepare and carry out character education in schools better. Learning cannot stop with the presentation of learning content but also to the activities and activities that encourage students to realize good attitudes and character in their lives. If this is not done, then character education only stops with character knowledge. Students will feel bored and not interested in learning. This is consistent with the facts on the ground, which is based on a questionnaire distributed by $60 \%$ of students stating that character education learning that takes place is not interesting so it does not encourage them to have good character. This is an obstacle that needs to be considered as stated by Lickona (2012:51), namely the desire for good character is needed to produce good character in action. After a student knows what a good attitude is, he needs to be guided to have a good moral desire (moral feeling). That means students not only know what good character values are, but they also have the desire to manifest those good attitudes in their daily lives. Students who already have an understanding of good character must be supported by conditioning good values that are applied in the education system (Leoni F and Clara, 2015:213)

This understanding is an important factor for schools to think about the implementation of character education. Otherwise, character education only stops at the transmission of knowledge without the embodiment of action. This is consistent with the facts obtained based on a distributed questionnaire that $85 \%$ of students stated that the character education they had taken so far did not encourage them to show good character. This is contrary to what was conveyed by Lickona (2012:51), that is the character must be manifested in life starting from someone who believes in the values of his life. Values eventually become beliefs (values) that are held and trusted in one's life. How a person can have the right character must begin with the knowledge of true values (moral knowing).
For this reason, it is necessary to carry out projectbased learning character education. According to Wena (2014:144) Project Based learning models are learning models that provide opportunities for teachers to manage learning in class by involving project work. Project work is a form of work that contains complex tasks based on questions and problems that are very challenging and guide students to design, solve problems, make decisions, conduct investigative activities, and provide students the opportunity to work independently. Project-based learning based character education will encourage students to apply good character in their daily lives.

Seeing the importance of knowing true values, the basis of project-based learning Christian character education is the Bible. The Bible records Jesus who was a person who possessed and showed the true character in his life. He set an example of how to think right, act right, and act right. What Jesus did became a perfect example of good and right character values in life. But from the character learning that has been done so far, based on a distributed questionnaire, it was found that only $27 \%$ of students stated that they understood the true character in Jesus Christ, while 50\% said they understood enough and $23 \%$ did not understand at all. This is contrary to what Sidjabat (2009:5) said, that the likeness of Jesus is the center of Christian education. Jesus' ideas and examples in his life journey in the world must be a guide for believers living their lives. That is why the material for teaching character education must be based on a person who resembles Jesus.

This is an important basis in the use of Christianbased character education teaching materials. Teaching material for Christian character education based on projectbased learning will influence the attitude of a student's life. This statement is in line with NoilbrohimBoiliu (2016:123) which states that character education starts from a correct understanding of the Christian faith. Students need to be educated properly so that it sinks into their souls which is then expressed in actions and behaviors that glorify God. The Word of God is now evident in the lives of students. Planting the right values will make students understand and be able to sort out the right and appropriate actions to be taken. In line with what was conveyed by Curtis Van Dam (2014:21) that Christian education taught to students will ultimately make them understand which values are indeed following the truth and are not trapped by wrong world values. Education encourages students to apply good values in their lives.

Based on the above understanding it can be concluded the importance of carrying out proper character education. Methods and teachings that involve students will encourage them to have correct moral knowledge, 
followed by a desire to do moral actions and finally realized with moral actions. This can be achieved when the teacher instills good and right values based on truth, the Bible. Christian education teaching materials are needed in the implementation of good character education.

\section{CONCLUSIONS AND RECOMMENDATIONS}

The results of this study are: 1) Character education conducted at the Kalam Kudus Surakarta Christian Middle School has not been maximized, this is due to the limitations of character education teaching materials so that it influences the interesting learning process to be unattractive and boring, 2) Students know what character is good but not yet able to realize the good character in daily life, 3) Good and interesting teaching materials are needed to help students realize a good character, 4) Christian character education materials based on project-based learning Project-Based Learning gives a positive and significant impact in the implementation of character education.

Based on the above conclusions, suggestions that can be given are: 1) Schools must pay serious attention to teaching materials and the implementation of character education carried out to arrive at the goals to be achieved, 2) Teachers need to continue to improve their abilities and master learning to present appropriate teaching materials and attracting students' interest to be involved in its implementation, 3) Students should increase their interest and desire in participating in character education in class so that they can show good character in their daily lives.

\section{REFERENCES}

[1] A. Budhima. 2017. Concepts and Guidelines for Strengthening Character Education (Konsep dan Pedoman Penguatan Pendidikan Karakter), Pus. Anal. dan Singkronisasi Kebijak. Sekertariat Jenderal Kementrian Pendidik. dan Kebud.

[2] Anthony, Michael J. "Introduction" dalam Introducing Christian Education: Foundations for Twenty-first Century. Ed. Michael J. Anthony. Grand Rapids: Baker, 2001.

[3] Apuke, O. D. (2017). Quantitative Research Methods: A Synopsis Approach. Kuwait Chapter of Arabian Journal of Business and Management Review, 6(11), 40-47.

[4] Boiliu, Noh Ibrahim. (2016). Mission of Christian Religious Education and the Problem of Child Morality (Misi Pendidikan Agama Kristen dan Problem Moralitas Anak). Jurnal PAK Regula Fidei, 1(1), 115-140

[5] Dam, Curtis Van. (2014). Character Education in Christian Schools. Master of Education Program Teses.
[6] Fathurrohman. (2015). Innovative Learning Models (ModelModel Pembelajaran Inovatif). Yogyakarta : Ar - Ruzz Media

[7] Francisca, Leonie and Clara R.P. Ajisuksmo. (2015). The Relationship Between Moral Knowing, Moral Feeling, and Moral Behavior in the Four Basic Competencies of Teachers (Keterkaitan Antara Moral Knowing, Moral Feeling, Dan Moral Behavior Pada Empat Kompetensi Dasar Guru). Jurnal Kependidikan, 45(2), 211-221

[8] Graham, Donovan L. (2003). Teaching Redemptively. Colorado Springs: ACSI.

[9] Hanafiah, Nanang. dan Cucu, Suhana. (2009). Learning Strategy Concepts (Konsep Strategi Pembelajaran). PT Refika Aditama. Bandung.

[10] Kienel, Paul A. (1978). The Philosopy of Christian School Education. California: Association of Christian School International.

[11] Lickona, Thomas. (2004). Raising Good Children: From Birth Through the Teenage Years. New York: Bantam Books.

[12] Lickona, Thomas. (2012). Educating for Character. Jakarta: Bumi Aksara.

[13] Lockerbie, D. Bruce. 2009. What Makes a Christian School Different (Apa yang Membuat Sekolah Kristen Berbeda)." Jurnal Transforming, 6(1), 14-19.

[14] M. Nasir, "Peringatan HUT Ke-74 RI Tahun 2019 'SDM Unggul, Indonesia Maju,'” Ristekdikti, pp. 1-5, 2019.

[15] Made Wena.( 2014). Strategi Pembelajaran Inovatif Kontemporer.Jakarta : PT Bumi Aksara.

[16] Majid, Abdul. (2006). Learning Planning (Perencanaan Pembelajaran). Bandung: PT Remaja

[17] Nasution, S., (1999). Curriculum and Teaching (Kurikulum dan Pengajaran). Jakarta: Bumi Aksara. cet-ke-3

[18] Pala, Aynur. (2011). The Need For Character Education. International Journal of Social Sciences And Humanity Studies, 3(2), 23-32.

[19] Prastowo, Andi. (2012). Creative Guide to Making Innovative Teaching Materials (Panduan Kreatif Membuat Bahan Ajar Inovatif). Yogyakarta: Diva Press.

[20] Raharjo, Sabar Budi. (2010). Character Education as an Effort to Create Noble Morals (Pendidikan Karakter Sebagai Upaya Menciptakan Akhlak Mulia). Jurnal Pendidikan dan Kebudayaan, 16(3) 229-238.

[21] Sidjabat, Binsen S. (2019). Teacher Strengthening for Character Education: See Congratulations Series Contribution (Penguatan Guru Pak Untuk Pendidikan Karakter: Melihat Kontribusi Seri Selamat), Evangelikal: Jurnal Teologi Injili dan Pembinaan Warga Jemaat, 3(1), 30-48.

[22] Sriyono. (1992). CBSA Teaching and Learning Techniques (Teknik Belajar Mengajar CBSA). Jakarta: Rineka Cipta

[23] Thorsos, Nilsa J., (2011). Christian Special Educators Responding to the Call to Serve: The Perception of Disability with a Christian Worldview Lens. International Christian Community of Teacher Educators Journal, 7(1), 18. 
International Journal of English Literature and Social Sciences, 5(3)

May-Jun 2020 /Available online: https://ijels.com/

[24] Trianto. (2014). Integrated Learning Model: Concepts, Strategies, and Their Implementation in the Education Unit Level Curriculum (Model Pembelajaran Terpadu: Konsep, Strategi, dan Implementasinya dalam Kurikulum Tingkat Satuan Pendidikan (KTSP). Jakarta. Bumi Aksara. 